\title{
A very unusual case of attempted suicide
}

\author{
Piotr Misiak, Sławomir Jabłoński, Katarzyna Dziwińska, Artur Terlecki \\ University Clinical Hospital No. 2, Military Medical Academy - Central Veterans' Hospital Lodz, Poland \\ Kardiochirurgia i Torakochirurgia Polska 2016; 13 (2): 145-147
}

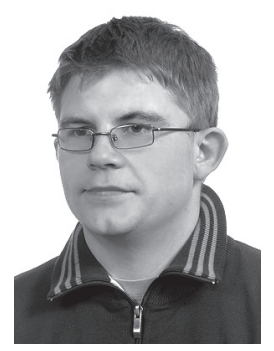

\begin{abstract}
We would like to present a case report of a very unusual suicide attempt. A 48-year-old female patient tried to commit suicide by stabbing herself with a kitchen knife into her neck. Suicide by self-stabbing is uncommon, constituting only $1-3 \%$ of suicide attempts. Patients with self-inflicted stab wounds may have a higher incidence of surgical interventions based on the stab location. Surprisingly, the mortality associated with this kind of wound is low. Most medical centers have very limited experience with this infrequent injury. There are only a few case reports and small series published in the literature of the subject.
\end{abstract}

Key words: suicide, neck and mediastinum injuries.

\section{Introduction}

Suicide by self-stabbing is uncommon, constituting only $1-3 \%$ of suicide attempts [1]. Patients with self-inflicted stab wounds may have a higher incidence of surgical interventions based on the stab location. Surprisingly, the mortality associated with this kind of wound is low. Most medical centers have very limited experience with this infrequent injury. There are only a few case reports and small series published in the literature of the subject.

\section{Case report}

A 48-year-old female patient was admitted to the emergency department due to a stab wound of the neck region (Fig. 1). She was fully conscious and her vital signs were in the normal range. The rescue team leader informed us that the patient had tried to commit suicide.

After the completion of the initial medical history, a thorough physical examination was conducted to detect any major vital organ damage to the neck and concomitant injuries. There was no presence of active bleeding, no bruit, no pulsatile hematoma, no sign of central neurological deficit, hemoptysis, stridor, hoarseness, dysphagia or subcutaneous emphysema. The patient, with full cardiopulmo-

\section{Streszczenie}

W poniższym artykule przedstawiamy przypadek niecodziennej próby samobójczej. Kobieta 48-letnia podjęła nieudaną próbę samobójczą poprzez ugodzenie się nożem kuchennym w szyję. Próby samobójcze polegające na samodzielnym zadaniu sobie ran kłutych są niezwykle rzadkie i stanowią ok. 1-3\% spośród wszystkich prób samobójczych. Powyższa grupa pacjentów cechuje się wyższym odsetkiem podejmowanych interwencji chirurgicznych w zależnosci od umiejscowienia rany wlotowej. Zadziwia fakt, że odsetek zgonów $w$ tego rodzaju obrażeniach jest niski. Większość ośrodków medycznych ma znikome doświadczenia w postępowaniu z takimi rzadkimi przypadkami. W piśmiennictwie spotyka się jedynie nieliczne doniesienia związane z tym tematem.

Słowa kluczowe: próby samobójcze, urazy penetrujące szyi i śródpiersia.

nary viability, was transported to the radiology department to conduct a complete computed tomography (CT) scan of the neck and thorax.

We were quite astonished with the results, which showed that the knife reached completely through the central mediastinum to the posterior mediastinum, attaining the aortic arch, gently leaning on the vessel's adventitia, and not damaging in the process any vital structure (Fig. $2 \mathrm{~A}$ and $\mathrm{B}$ ). The $\mathrm{CT}$ scan revealed a bilateral pneumothorax, due to which bilateral drainage of the pleural cavity was administered through the second intercostal space in the midclavicular line using Thorax $24 \mathrm{~F}$ drains (Fig. 3). After completing the preliminaries mentioned above, the patient was transported to the operating room.

A left-sided anterolateral thoracotomy was conducted in the supine position. The access limited the direct view into the posterior mediastinum, but our idea was to reduce any patient rotation to a minimum, so that the injury to the vascular wall of the aorta was not compounded.

After ensuring that the tip of the blade did not penetrate completely through the aortic vessel wall, but only bordered the surface of adventitia of the aortic arch, the first assist removed the knife. 


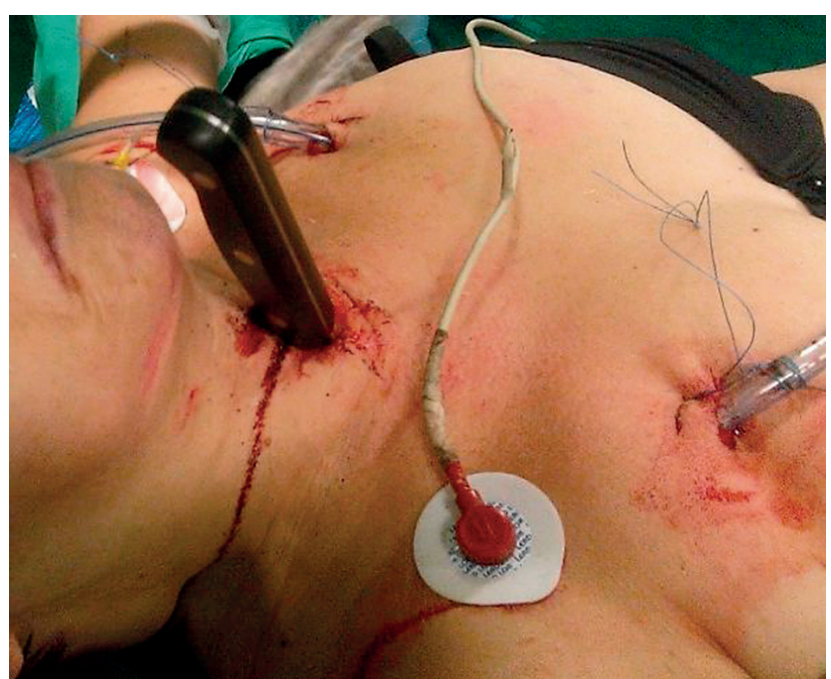

Fig. 1. Position of retained blade

Subsequently to the removal of the blade, no hemorrhage to the pleural cavity was noted, and at this stage the decision to leave an additional drain in the left pleural cavity and to close the thorax was made.

Afterwards the neck injury exploration was begun. To extend the post-injury wound a cut along the medial edge of the right sternocleidomastoid muscle was applied. During the dissection towards the trachea no damage to the vital anatomic structures was noted. However, after the deep layers behind the trachea were explored, tangential damage to the tunica adventitia of the esophagus was discovered. The esophageal injury was attended to with simple monolayer interrupted stitches. A Redon drain was left in the attended injury site, which was removed on the second day after the surgery. The upper drains from the pleural cavity were removed on the third day after surgery, and the left lower drain on the second day. The patient was discharged to a psychiatric hospital on the seventh day after the surgery. During the follow-up visit on the tenth day the stitches were removed, and no complications were noted.

\section{Discussion}

Penetrating neck trauma is responsible for less than $5 \%$ of all trauma admissions [2]. These injuries are unique and challenging, especially those which penetrate to the thorax cavity. The abbreviated surgical exploration is also in many cases insufficient to answer whether an extended surgical procedure is necessary.

According to Roon and Christensen, the neck can be divided into three zones: zone I - between the sternal notch and the cricoid cartilage; zone II - between the cricoid cartilage and the lower border of the mandible; and zone III - between the lower border of the mandible and the base of the skull. Up to $80 \%$ of injuries involve zone II. According to international literature, the most frequent site of injury is the aerodigestive tract, followed by the major vascular structures and nerve injuries [2, 3].

Although zones I and III are protected by bones, penetrating trauma to this area is more dangerous than to zone II because of the proximity of the thorax and skull base. When lack of symptoms and absence of neck swelling do not exclude the possibility of underlying serious injuries, the knowledge of the common consequences of each zone of injury can provide some idea of the possible extent of the internal damage.
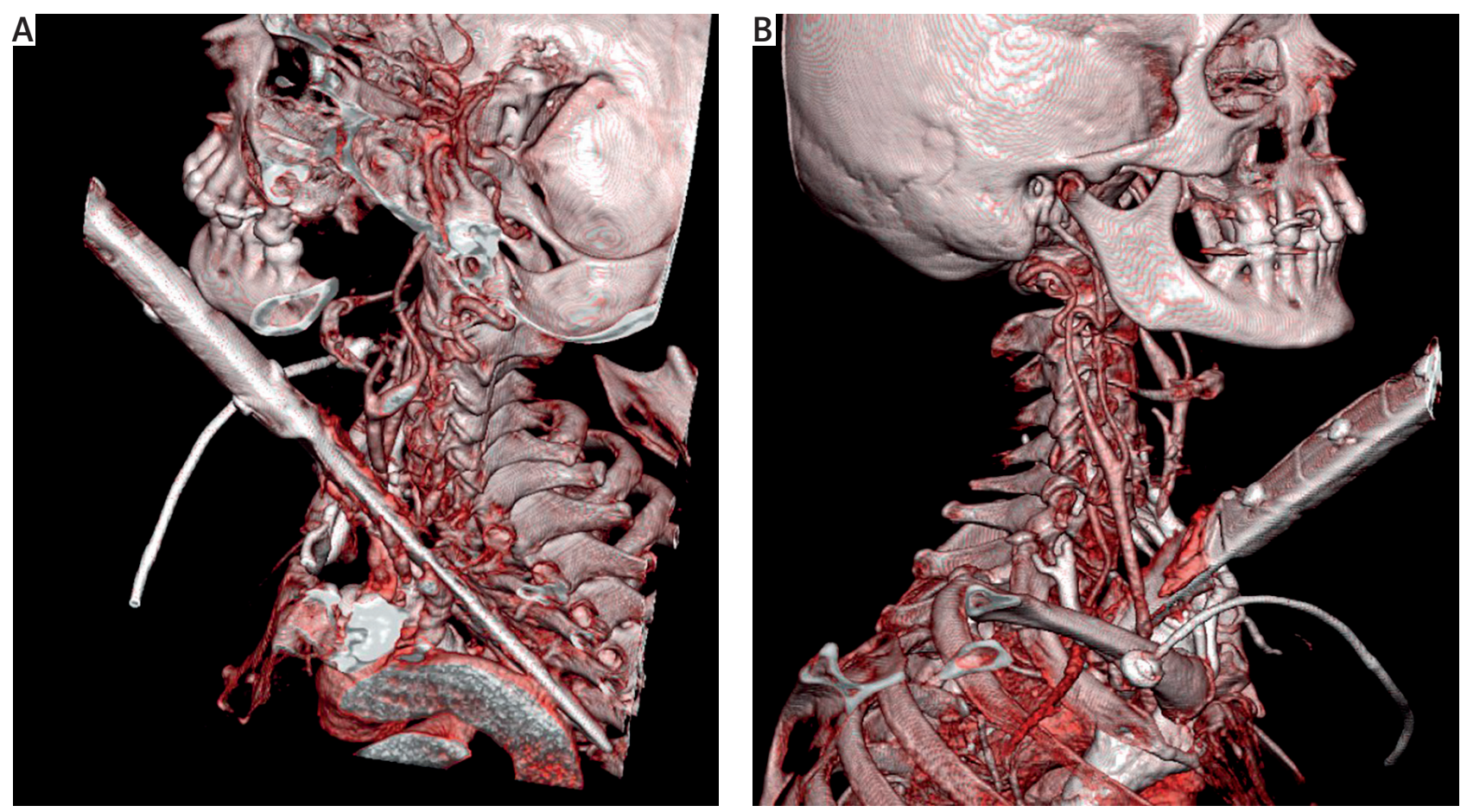

Fig. 2 A, B. Position of retained blade in 3D CT 
Unstable patients usually require an urgent operation due to severe bleeding or concomitant injuries. Hemodynamically stable patients require extended diagnostic procedures to plan the final surgical procedure. In this particular case, where our patient showed full cardiopulmonary viability, extended radiological diagnostics (the CT scan of the neck and thorax) allowed detailed visualization of the trajectory of the blade, which was observed to be $14 \mathrm{~cm}$ in length and penetrated into the posterior mediastinum, bordering the vessel wall of the aorta. This diagnostic method also made the concomitant injury of the bilateral pneumothorax apparent, although it did not reveal the damage to the tunica adventitia of the esophagus in the cervical region. This case is extremely unusual for at least two reasons: firstly, the self-inflicted stab wound is an uncommon method of suicide attempt, and secondly, to date we have not come across an analysis of a wound penetrating from the neck region through the central mediastinum to the posterior mediastinum, reaching the vessel wall of the aortic arch and not damaging any vital structures in accessible databases of international literature. Medical management in such cases, due to their infrequency, requires, besides the individual approach, excessive caution and control. No unified recommendations for such injuries have been established yet $[4,5]$.

The importance of using a spiral CT scan in hemodynamically stable patients is underlined in the international literature, commonly combined with the oral administration of a water-soluble contrast medium in the case of esophageal damage, or with angiotomography in the case of vessel damage $[4,5]$. This diagnostic method in most cases expedites the decision involving the approach method and the extent of the final surgical procedure, provides information on the anatomic ratios of the foreign body to the vital organs, and allows one to foresee the possible consequences of removal of the foreign body. Moreover, it can make smaller injuries apparent, which when not discovered can contribute to the development of long-term complications, such as mediastinitis, mediastinum abscess, or dissecting aneurysm of the aortic arch vessels [4]. In the described case, however, the CT scan did not reveal the intraoperatively discovered damage to the outer esophagus wall.

We have to remember that patients with retained blades and vessel injuries can be hemodynamically stable on admission, because the blade acts as a local tamponade. Unplanned extraction of the blade may result in massive hemorrhage, hemodynamic deterioration and death. Sclafani et al. recommended routine angiography in the case of zone III neck wounds, whereas Atteberry et al. considered that physical examination alone is sufficient for penetrating zone II neck trauma [5-8]. We prefer to conduct a CT scan in all cases in hemodynamically stable patients. Altho-

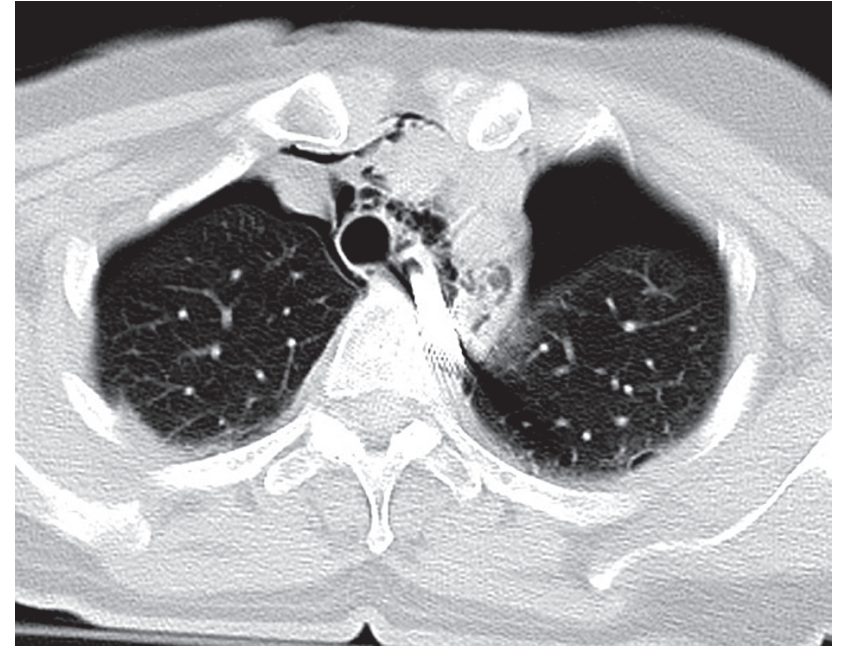

Fig. 3. Bilateral pneumothorax

ugh our experience is limited, we believe, similarly as Sobnach et al., that patients should be properly investigated prior to extraction of a retained blade [4].

Like other authors, we believe that patients with neck injuries of various etiology should be admitted to multi profile trauma centers, since saving their lives may depend on the cooperation of many different specialists and implementation of multiple diverse therapeutic procedures $[2,3,6,9,10]$.

\section{Disclosure}

Authors report no conflict of interest.

\section{References}

1. Badger JM, Gregg SC, Adams C. Non-fatal suicide attempt by intentional stab wound: clinical management, psychiatric assessment, and multidisciplinary considerations. J Emerg Trauma Shock 2012; 5: 228-232.

2. Nason RW, Assuras GN, Gray PR, Lipschitz J, Burns CM. Penetrating neck injuries: analysis of experience from a Canadian trauma centre. Can J Surg 2001; 44: 122-126.

3. Smith GA. Knife-related injuries treated in United States emergency departments, 1990-2008. J Emerg Med 2013; 45: 315-323.

4. Sobnach S, Nicol A, Nathire H, Kahn D, Navsaria P. Management of the retained knife blade. World J Surg 2010; 34: 1648-1652.

5. Atta HM, Walker ML. Penetrating neck trauma: lack of universal reporting guidelines. Am Surg 1998; 64: 222-225.

6. Vishwanatha B, Sagayaraj A, Huddar SG, Datta RK. Penetrating neck injuries. Indian J Otolaryngol Head Neck Surg 2007; 59: 221-224.

7. Sclafani SJ, Cavaliere G, Atweh N, Duncan AO, Scalea T. The role of angiography in penetrating neck trauma. J Trauma 1991; 31: 557-62; discussion 562-3.

8. Atteberry LR, Dennis JW, Menawat SS, Frykberg ER. Physical examination alone is safe and accurate for evaluation of vascular injuries in penetrating Zone II neck trauma. J Am Coll Surg 1994; 179: 657-62.

9. Page RD, Lye RH. Stab wounds of the neck: potential pitfalls in management. Arch Emerg Med 1989; 6: 225-229.

10. Sharma OP, Blaney J, Oswanski MF, Assi Z, Disalle R, Latocki V. Stab wound of the neck with contralateral hemo-pneumothorax. J Emerg Med 2010; 39: 135-138. 